Article

\title{
Revitalization Education in Problem Areas as a Tool for the Implementation of Social Welfare
}

\author{
Beata Skubiak (i)
}

check for updates

Citation: Skubiak, B. Revitalization Education in Problem Areas as a Tool for the Implementation of Social Welfare. Sustainability 2021, 13, 11291. https://doi.org/10.3390/ su132011291

Academic Editors: Anna Nowak and Armand Kasztelan

Received: 14 June 2021

Accepted: 24 September 2021

Published: 13 October 2021

Publisher's Note: MDPI stays neutral with regard to jurisdictional claims in published maps and institutional affiliations.

Copyright: (C) 2021 by the author. Licensee MDPI, Basel, Switzerland. This article is an open access article distributed under the terms and conditions of the Creative Commons Attribution (CC BY) license (https:/ / creativecommons.org/licenses/by/ $4.0 /)$.
Faculty of Economics, Finance and Management, Uniwersytet Szczeciński, Mickiewicza 64, 71-101 Szczecin, Poland; beata.skubiak@usz.edu.pl; Tel.: +48-91-4441974

\begin{abstract}
Achieving social well-being in problem areas requires social and economic activation, which is made possible by a change in the attitudes and behavior of the area's inhabitants. In this systematic review article, the author points out that in order for current public interventions for people at risk in problem areas to be effective, the use of available research by neurobiologists is required. To this end, the author: (1) made a synthetic characterization of problem areas in the world, with particular emphasis on social challenges; (2) reviewed both the available research written by neuroscientists and their subsequent conclusions, which may contribute to better explanations of the social consequences of transformation; (3) on this basis, the author formulated conclusions and recommendations for decision makers. In addition, a review of available research by neuroscientists will help to understand why efforts so far targeting marginalized social groups have been ineffective or insufficient. Revitalization education is defined as all the processes and interactions that aim to change the attitudes and behaviors of people, in particular children and adolescents, in order to contribute to the integration and inclusion of people at risk of social exclusion, and thus improve their well-being. Revitalization education should be directed at people who are caught up in a negative loop of social patterns. Since their fate is shaped by the influence of parents and teachers, the method used for reconstructing positive life patterns towards prodevelopment skills and competences should also be directed at these groups. The article discusses: social problems of marginalized areas; the impact of neuroscience on economic decision making; and recommendations formulated for educational activities.
\end{abstract}

Keywords: problem area; neuroscience; education; sustainable development

\section{Introduction}

Sustainable development, problem areas and education: what connects these phenomena and what makes their interactions interesting and important for study? The answer can be found in many fields: what today determines the nature of problematic areas? How is it possible to achieve the assumptions of sustainable development, especially with regards to the social aspect in a situation where there is a tendency to increase differences in socioeconomic development and to increase inequalities on various levels (economic, social, educational, digital, financial etc.)? The scale of these differences is increasing, becoming a contemporary challenge for the policy of sustainable development [1]. Unfortunately, economic and social development on our planet is not taking place in a sustainable manner. One of the reasons is unfair trade.

In research on the spatial differentiation of socio-economic development, one of the most important threads, vividly discussed in the literature, is what are the main causes of this process. Questions about the causes, i.e., the conditions, determinants or factors conducive to the emergence of spatial differentiation, and in principle, the deepening or elimination of the degree of socio-economic differentiation in space, seem to be of a fundamental nature [2]. In this context, it is crucial to recognize the essence and effects that impact contemporary processes of socio-economic changes that cause spatial differentiation of socio-economic development. 
When analyzing strategic documents, in relation to problem areas in the new programming period, attention is paid to soft development factors. Therefore, the field of soft development factors is a necessary place to focus any interventions. Big challenges, including new ones related to the effects of the COVID-19 pandemic, emerge with new force, especially in the area of education, lifelong learning, health and the integration of excluded people or people at risk of social exclusion and migrants. Children and adolescents are particularly vulnerable to the effects of COVID-19. Although they are less likely to experience severe physical manifestation of the disease from the SARS-CoV-2 virus, the psychological and educational effects of a pandemic can be very severe for them, and sometimes will last much longer than the pandemic itself. Scientific research shows that young people are particularly affected by stress related to the COVID-19 epidemic [3-7]. This is due to, among other things, the destabilization of family life, isolation from their peers, the need to change their habits and the loss of safe routines in their daily lives [8]. Anxiety and uncertainty are also amplified by intense exposure to negative information about the pandemic and its consequences. There is also stress related to developmental changes that are natural at this age, in the biological, social and psychological spheres, including qualitative changes in how they think and experience the world.

Research shows that one aspect of the pandemic that has a particularly negative impact on the psychological condition of young people is forced confinement at home, which not only condemns them to partial inactivity and isolation from their peers, but also very often deprives them of the privacy and intimacy so necessary at the developmental age [4,5,9]. Young people, especially those on the verge of maturity, may also be concerned about poorer prospects for their future: the pandemic may destroy their dreams, aspirations and hopes that they have for success in their lives. Additionally, when many parents and legal guardians face serious difficulties, young people may become victims of verbal, mental and physical abuse, which can be experienced directly or indirectly [3]. During the pandemic, the periodic school closures have clearly shown how important universal school is, not only in providing basic knowledge to young members of society, but also as an institution enabling their proper development [10]. The distance learning system means that many children face educational problems, and it makes it more difficult for them to catch up to their peers. The available empirical studies indicate that the first spring wave of the epidemic has already negatively impacted educational results, i.e., school grades, for that calendar year. This was caused by school closures and it increased inequalities between schools and between students themselves [11]. On the other hand, on the basis of scientific research available before the pandemic, we can try to estimate the economic scale of the effects of such breaks on proper school education and the detriment in education for these students. Exclusion from school education, equal to the loss of $1 / 3$ of the school year, leads to a loss in future individual earnings by an average of $3 \%$ throughout the entire life span [12]. Due to the already observed differences of the impact of school closures on student performance, it can be expected that the future income of the affected years will not only be lower but will also be characterized by higher inequalities.

Due to the global nature of learning interruptions, economic losses can occur not only at the individual level, but also at the level of the economy as a whole. In an optimistic scenario-where the education system's functioning irregularities only last for around half of the school year-losses to the country's economy may even exceed 1.5\% of GDP (gross domestic product) for the next several dozen years [12]. This results from today's children and adolescents being unable to develop the necessary cognitive skills that they would have in a normal school year, which in adulthood may translate into lower human capital, including: weaker learning and cooperation skills, lower creativity, lower independence and lower innovation. These abilities are key for the development of a modern knowledgebased economy.

A separate issue is entering professional life during a period of deep recession, which according to available studies, may have a long-term negative impact on the future earnings of today's youth. The wages (earnings) of people entering the labor market under unfavor- 
able conditions are lower on average, from $3 \%$ to $8 \%$, compared to those entering the labor market during a prosperous period, and the difference lasts up to ten years [13-15]. Entering the labor market during a recession is also associated with such unfavorable phenomena as: increased mortality at middle age, lower probability of marrying or finding a partner for life, lower fertility and higher probability of relationship breakdown [16]. Research results indicate that for children and adolescents, economic turmoil-even when perceived as temporary-can have a long-lasting and negative impact on their lives and health.

Thus, the above-mentioned effects will intensify already existing socio-economic problems of problem areas and contribute to increasing inequalities.

After objectively identifying problems and needs, consensus and long-term consistency in action are necessary in this regard. It is postulated that in the new programming period, the cohesion policy (to a greater extent and in a long-term manner) should shape determinants in order to stabilize positive structural changes in a nation such as human and social capital, preparing various territorial units for new dimensions of competition and new types of crisis phenomena.

Such formulated recommendations drawing on the field of activation and stimulation of development, especially in problem areas, are correct in principle and in line with the contemporary paradigm of development. Unfortunately, to date the experience of implementing the cohesion policy and reducing development disproportions has not brought about the intended effects. The question is, why is it that despite prioritizing problem areas for the allocation of funds, allocating increased funds to reduce the development differences has not resulted in the intended effects being achieved, which is confirmed in numerous scientific studies and state reports.

Moreover, the direct experiences of the author of the text working with excluded people (children and young people at risk of social maladjustment and also inhabitants of problem areas) and participating in numerous initiatives for equalizing development opportunities, prompted us to seek answers about the reasons for a lack of progress in reducing development differences. The limited effectiveness of previous attempts to counteract marginalization showed the scale of the difficulties that both local communities and institutions offering support programs have to face.

In this article, attention will be focused only on actions taken in relation to human capital, because the implementation of sustainable development in problem areas requires social and economic activation, which is brought about by a change in the attitudes and behaviors of the problem area's inhabitants.

The whole article is an extension of knowledge about problem areas and the possibility of their activation in the social and economic dimension. Therefore, it will contribute to making more effective decisions in order to implement sustainable development in the socio-economic dimension.

Two valuable conclusions can be drawn from the analysis. The first is a better understanding of the problem areas and the reasons for their emergence, especially in countries that have undergone system transformation. The second is the complexity and subtlety of social problems, their causes and effects.

Revitalization education, according to the author, is defined as all processes and interactions aimed at changing the attitudes and behaviors of people, especially children and adolescents, that should contribute to the integration and inclusion of people at risk of social exclusion, and thus contribute to improving their welfare. Revitalization education is a concept formulated by the author of this article, therefore there is no scientific literature that discusses this issue more broadly and that one could refer to.

Access to knowledge proves to be a fundamental necessity in an environment where efficiency is paramount and where sustainable development is based on a minimum input of resources in return for maximum baseline values. In the context of problem areas that are in a state of economic collapse, where local identity is not developed and contemporary development processes (metropolization) put urban centers first-at the 
expense of problem areas-as the engine of development and economic growth, public policies focused on the needs of the former are of prime importance.

\section{Materials and Methods}

Today, in almost all fields, attempts are being made to scientifically explain the natural phenomena we encounter, in order to understand them and use this knowledge for the common good. When addressing the problem of exclusion, marginalization, social threat, dysfunction and inherited poverty, some try to popularize the belief that these phenomena are mysterious and cannot be researched. This article is a theoretical discussion based on the existing views and research in the field of neuroscience on the impact of the external environment on the community's behaviors and attitudes who are from the problem area. Recently, there has been a noticeable increase in interest on the results of brain research from psychologists and educators, and on that basis, efforts are being made to verify the methods of teaching and learning used so far. The author will also discuss the need for changes in the approach to the phenomena of marginalization and social exclusion as well as verifying existing public intervention, which were addressed to the inhabitants of problem areas. The undertaken discussion will aim at establishing the premises and conditions for sustainable development in the social aspect and the components that shape socially sustainable development $[17,18]$.

\section{Results}

This section is divided into subheadings. It provides a concise and precise description of the experimental results, their interpretation, as well as the experimental conclusions that can be drawn from them.

\subsection{Genesis, Problems and Social Challenges of Problem Areas}

There are many different proposals for defining this concept in the scientific literature. They generally reflect the various authors' research discipline. Different approaches to this issue mean that the term problem area does not have an unambiguous definition and it is understood in various ways. In studies on this subject, terms such as: conflict areas, scarcity areas, depressive areas, difficult areas, areas of production reserves, disadvantaged areas, areas of threats, areas lagging behind in development, less developed areas, and marginal or peripheral areas, are used interchangeably. In many cases, they are treated as synonyms of the term "problem area" [19-25]. However, their connotation is different, and such free use of the concepts may lead to many misunderstandings, and even serious errors. The approach to problem areas and the way of identifying them can be very different. For example, in Brazil during the great famine caused by drought, the location of the problem areas was derived from the national food waste map. On the other hand, in Great Britain, the criterion of their delimitation is the specific level of the unemployment rate in society according to areas of the country [26]. In the USA, the problem areas of E. M. Hoover [27] include Appalachia, as a great agricultural poverty zone, and five other areas (Upper Great Lakes, New England, Coastal Plains, Ozarks, Four Corners) covering at least two states. Criteria for their recognition include: depletion of mineral resources, unfavorable natural conditions for agriculture, increased soil erosion, dynamic deforestation process and depopulation. Federal authorities treat them as areas of special concern that require assistance and separate spatial planning studies.

The surprising criteria for distinguishing problem areas in the USA were used in the 1960s by B. Chinitz [28]. Among them-apart from Appalachia, Indian reserves and the so-called depressed rural areas - there were regions of high income and rapid economic development. Those areas were included in the group of problem areas due to the fact that there were high levels of unemployment in those regions of high income and rapid economic growth during certain periods.

One of the major problem areas in Western Europe is the so-called "Mezzogiorno" covering southern Italy (incl. Sardinia and Sicily). It is characterized by much lower 
socio-economic development than the northern part of Italy. It is manifested by a relatively low net income per capita, fragmentation of farms, traditional forms of farming, high unemployment, etc. The reasons for the creation of such a large problem area include: unfavorable environmental conditions; lack of interest from the state during the period when this negative phenomenon was increasing; cultural and social backwardness.

In Austria, the problem area is the eastern border area. Among its specific features, A. Mync lists: an area neighboring other countries with relatively weak economic ties, a peripheral location in relation to EU areas, insufficient economic development (low income, unemployment, poor infrastructure) and where there is an outflow of the population.

A similar situation occurs in Hungary. On the basis of an analysis of the standard of living of the population, P. Klekner [29] showed the existence of regions that were backward in development, located in the border area (the north-east and south-west of Hungary). That area, with its 573 localities, has been included in a special government program.

On the other hand, in Greece, N. Konsolass [30] identifies problem areas using 23 diagnostic features, characterizing the demographic and economic situation using the scale of prefectures. On this basis, he included almost all the Greek islands and the southern part of the Peloponnese as a problematic area.

The analysis shows that the approach to the problem of the problematic area is very diverse, but all the concepts are aimed at selecting regions with unstable development opportunities.

In the scientific literature, you can find many definitions for "problem areas" because different authors condition the problem in different ways. On the one hand, multidimensional determinants of reality in the geographical sense, lead to the emergence of many different types of problem areas, and consequently, to many approaches in understanding (defining) them. On the other hand, the subjective perception of the problem, from the point of view of a given author, also plays an important role. For these reasons, there are countless concepts and definitions in the scientific literature that try to define the term "problematic" (area). For this reason, there will never be a definition that will objectively explain this term and which would be seen by most authors as something like "technicus terminus".

In addition, there is great freedom in the use of the terms: region, zone and area, the spatial extent of which is not the same, and their designations are also different [31] (p. 13).

In the European Union, the essence of planning and programming in problem areas corresponds to implementing the principle of concentration from the European Union's regional policy. In addition to the principles of programming, partnership and complementarity, it is the basic principle that the way the EU instruments impact regional development to create social and economic cohesion, and more recently, territorial (spatial) cohesion, is determined. This principle determines the method for allocating support funds to specific problem areas.

Most often, however, the concept of problem areas is understood as areas characterized by a low level of economic development, showing poor development dynamics and characterized by the occurrence of negative social effects of the transformation process. Thus, the concept of problem areas has an unequivocally pejorative meaning and is directly related to the regional policy based on the equalization model-assuming the need to support the weakest areas in order to achieve regional convergence.

For the purposes of this article, it was assumed that the problem area is characterized by: low levels of economic development; low levels of inhabitants' income, which may be the result of low demand for goods and services; poor infrastructure (transport, education, etc.); a high percentage of social pathologies; increased migration; and low levels of local entrepreneurship.

In the case of Central and Eastern European countries, one of the reasons for the emergence of problem areas is the systemic transformation that took place within the framework of global mega trends and was associated with the transition from industrial 
civilization to postindustrial civilization and, additionally, with the transition from the socialistic system to the capitalist system. This transformation, resulting in the return of socialistic Central and Eastern Europe to the bloc of Western European democratic states, whose socio-economic system was based on the assumptions of a mixed-market economy, launched in those regions profound changes that took place under the simultaneous influence of all megatrends, i.e., globalization, integration and postmodernization processes. This resulted in far-reaching economic and social consequences, the results of which were not always positive. The effects of systemic transformation in the countries of Central and Eastern Europe are: stabilization and liberalization of the economy; reprivatization and privatization of the economy; restructuring of the economy; postindustrialization and development of services; and the inflow of foreign capital. The economic-social dimension of the systemic transformation is also associated with certain negative effects, such as unemployment, social polarization or pauperization [32-36]. The socio-political dimension of systemic transformation is primarily related to the democratization of political and social life and includes such effects as: the creation of democratic political principles and democratic law, the emergence of a civil society and a multi-party political system of government, deconcentration and decentralization of power, and the introduction of a governmental self-government administrative system at the local level. In the Central and Eastern European post-socialist countries, postmodernization processes (as well as modernization processes) were launched because of changes related to the political transformation at the turn of the 1980s and 1990s. The collapse of the socialist economic system and the departure from a centrally controlled economy in favor of a free-market economy launched postmodernization processes and, in a way, "opened" these countries up to integration and globalization processes. As in the case of Western European countries, these processes proceeded in Central and Eastern European countries with different intensity and effects. This resulted, on the one hand, from the social and cultural conditions and the existing organization of socialist economies and the regulatory system, and on the other hand, from the adopted model of transformation. An additional element intensifying the postmodernization processes, both in terms of the scale and the size of its effects, was the size of the country (and its economy) and the branch structure. In the smaller and relatively diversified economies of Central and Eastern Europe (e.g., the Czech Republic, Slovakia, Hungary, Bulgaria, Slovenia, Croatia and Estonia), these processes were slightly faster than in larger economies and/or those heavily dependent on technologically backward industries (e.g., Poland, Romania, Lithuania, Latvia). Nevertheless, at the beginning of the 1990s, all the Central and Eastern European countries faced the challenge of economic liberalization, marketization of the economy and development of the small and medium-sized enterprise sectors, and the necessity to "catch up" based on their technological and organizational deficits. Additionally, these countries had to rebuild, or build from scratch, civil society and create norms and institutions regulating the social and economic spheres. In order to undertake real economic competition, these countries had to rebuild and modernize material, human and social capital in a relatively short time, with the support of financial capital and innovations from Western countries, which contributed to a kind of economic and socio-cultural "neo-colonization" of these countries. However, as a result of these processes, these countries showed (and continue to demonstrate, especially thanks to the positive effects of the European Union integration) an above-average pace of postmodernization changes compared to Western European countries [37].

The mega trends mentioned above (transformation, economic integration, globalization and postmodernization) play a key role in shaping contemporary processes of socio-economic development. Despite the fact that it is difficult to analyze the individual impact of each of them, as they interact together (externally in relation to endogenous processes) and interpenetrate one another, as well as the fact their influence varies in time and space, this article focuses only on the socio-economic effects of the political transformation. The impact of mega trends on socio-economic processes also requires a fresh look at the factors of socio-economic development. At the same time, considering the changes of the 
factors of socio-economic development from the point of view of mega-trend influences, we should take into account the specificity of a given territory, which is-among other factors-a consequence of its historically distinct properties, largely related to the different development paths of Western Europe and Central and Eastern Europe. The results of the conducted analysis confirm the validity of adopting a place-based policy paradigm as the basis for the optimization of cohesion policy activities. Unfortunately, its use faces serious obstacles at the stage of operationalization, which leads to a situation where most stakeholders know what it is, but only a few of them make successful attempts to use it in the practice of public intervention. The dissemination of this approach, which takes full advantage of the consequences of mega-trend influences on the transformations of the socio-economic development factors, requires decentralization of competences and finances. This will enable the flexible adaptation of interventions to objectively identify resources and development opportunities, in accordance with the principle of evidence-based policy [38,39].

Development experts believe that the most effective method for reducing social marginalization is the involvement of development experts in the economic process, and in social and political life [40].

Social phenomena also have an impact on the processes of economic development and for this reason the problem of marginalization and social exclusion is important. Marginalization, indirectly caused by social inequality and stratification, is caused by many other factors as well. The important ones include: unemployment, poverty, alcoholism, drug addiction, homelessness, and the problem of dysfunction and disability. Marginalization is also associated with expulsion, isolation of the individual, excluding them from society and their lack of acceptance in their environment. Moreover, this phenomenon concerns an inability to benefit from social life. Marginalization is quite often located next to social exclusion or is generally identified with it. It concerns people, families and groups of people who live in difficult economic conditions (material poverty), and who are affected by unfavorable social processes resulting from massive and dynamic development changes, for example, de-industrialization, economic crisis and the sudden collapse of industries nationally or regionally; these people have not been equipped with life capital enabling them to maintain a normal social position, have appropriate qualifications and they have not been able to enter the labor market or start a family, which additionally makes it difficult to adapt to the changing social and economic conditions.

Marginalization is the process of pushing a specific group or groups of people to the margins of society, preventing them from actively engaging in various spheres of activity, limiting their identity or place in the community. Through direct and indirect processes, marginalized groups may be pushed to the background of society or feel as if they are less important than those with more power or privileges in society. Individuals and groups may be marginalized on the basis of many aspects of their identity, including, but not limited to: racial identity, gender identity, ability, sexual orientation, socio-economic status, sexuality, age and/or religion. Some individuals identify with multiple marginalized groups and may experience further marginalization as a result of their intersecting identities [41-43].

While exclusion and marginalization are terms that are often used interchangeably, these terms have different meanings. Marginalization refers to a set of processes as a result of which some individuals and groups of people experience systematic disadvantages in their interactions with dominant social, political and economic institutions. Disadvantages stem from class status, social group identity (kinship, ethnicity, caste and race), political affiliation, gender, age and disability.

Exclusion, when it is not synonymous with marginalization, describes the results of marginalization. Examples include under-representation, poor access to legal systems and denial of public services.

In Poland, excluded people are those at risk of, or experiencing, poverty or social exclusion, including in particular:

- temporarily unemployed people; 
- constantly unemployed people - that is, those persons belonging to the third group and are profiled as away from the labor market, based on the meaning described in Art. 33 from the Act dated 20 April 2004 on employment promotion and labor market institutions;

- $\quad$ people with low qualifications;

- $\quad$ people with disabilities (including mental disorders);

- excluded children and adolescents or those at risk of social exclusion;

- homeless people;

- being in an environment of socially excluded people (including families of excluded people or people at risk of poverty and social exclusion), whose participation in the project is necessary for the effective support of those at risk of poverty or social exclusion.

- On the other hand, marginalized communities are residents-especially childrenwho live in a negative loop that perpetuates nondevelopmental life patterns and where there is a culture of poverty and life helplessness, which is then transferred to the next generations.

- The main barriers that prevent this group from changing their social status include:

- lack of financial resources to participate in educational and cultural development activities;

- life and social burnout;

- low self-esteem;

- the feeling of a lack of competence.

Marginalized communities, as long as they are not mired in apathy and inertia, think about changing their fate in a magical way (e.g., winning the National Lottery) or dream of fleeing elsewhere. The existence of marginalized communities and socially excluded groups in Poland is one of the main factors that is taken into account when defining (delimiting) problem areas.

Active social inclusion of marginalized people is carried out using a wide range of instruments for professional activation such as participation in the activities of the Social Integration Center, participation in the Social Integration Club classes, work apprenticeships or internships in a social cooperative or other entity or enterprise, the financing of a job trainer, vocational counselor or job placement. The educational instruments include referring and financing school activities related to completing primary, secondary, postsecondary or post-college education and the related costs, as well as referring individuals and financing classes as part of education. Furthermore, the use of lifelong learning instruments, aimed at gaining a profession or vocational qualification, which includes, directing and financing classes as part of raising key professional competences or acquiring new competences and professional skills, enabling professional activation, organizing and financing support services with educational activation (e.g., an educational broker), financing studies for people leaving social support programs, educational institutions, foster care, social care and health care, referring and financing school activities related to completing primary, lower secondary, upper secondary or postcollege education and related costs. Additionally, the social instruments that are applied are the organization and financing of training in social competences and skills, the organizing and financing of specialist counseling, as well as providing information on rights and entitlements aimed at restoring life independence, including a return to the labor market, organizing and financing individual and group counseling and supporting increasing life competences and social and professional skills which ultimately enable a return to social life, including a return to the labor market and professional activation and social work. Health instruments include referral and financing, providing psychological, family or psychosocial therapy for families or individuals, directing and financing a corrective and educational program for people being abused by domestic violence (referred to in the regulations on counteracting domestic violence), referring and financing a psychotherapy program, providing addiction treatment in the case of people addicted to alcohol, that is, the provision of understanding 
sobriety and counteracting alcoholism, referring and financing therapeutic programs in a health care institution for people addicted to drugs or other intoxicants, that is, those suffering from drug addiction [44].

Marginalization can have a negative impact on the mental, emotional and physical health of marginalized people. Some possible psychological and emotional responses to marginalization include: anger, anxiety, paranoia, fear, depression, sadness, hopelessness, powerlessness, self-doubt and isolation [45].

People who experience marginalization are less involved in the economy. Their sources of income are different, and for most marginalized people their sources of income depend on cash benefits.

Marginalization is an experience that affects millions of people around the world. Marginalized people have relatively little control over their own lives and the resources available to them. This results in them being handicapped in contributing to society. A vicious circle arises in which the lack of positive and supportive relationships means that they cannot participate in local life, which in turn leads to further isolation. This has a huge impact on the development of people as well as the entire society. Since the goal of development is to create an environment that enables people to enjoy a productive, healthy and creative life, it is also important to tackle the issue of marginalization. Development is always broadly understood in terms of mass participation. Marginalization deprives the vast majority of people around the world from participating in any kind of development.

Economic science should therefore be particularly well prepared to help people respond to the challenge of their marginalization in a constructive way.

\subsection{Transformational Shock and Its Social Consequences in the Context of Neuroscience}

Modern neurosciences offer great opportunities to study the relationship between the biological and social processes. Therefore, it is not surprising that economists also became interested in this domain. The problem of marginalization was noticed and appreciated in 2002, when the Nobel Prize Chapter honored three economists for their research that addressed the issue of global poverty. Banerjee, Duflo and Kremer broke the problem down into smaller parts, making it easier to understand. They assessed the scale of the problem, and how to tackle its causes. The scientists' idea was explained as the issue of improving children's health. The Nobel Prize laureates proposed that in order to solve the problem it was necessary to investigate the factors that caused it. In their view, it is therefore important to look at education methods, as well as health systems, agriculture and the availability of money loans. Kremer, Banerjee and Duflo have experimentally shown where money is wasted on education. They also indicated where the money should be directed, as well as how to organize the education of the youngest children. In 2017, Richard Thaler joined the group of laureates of this prestigious Nobel Prize award as another representative of this trend.

But does a "normal" economist need theories and techniques from neuroscience? Do they help in theory progress and decision making? Do they allow us to see something inaccessible by other means? Today, it can be said with full confidence that neuroscience helps to answer these issues. Contemporary research proves that epigenetics can shape a person's personality, and thus their behavior.

Epigenetics is a new branch of genetics and biomedicine that discovered a second gene code gives power over the genotype. Epigenetics proves that man is not a slave to his genes, but they can be modified by a healthy life, physical activity and a proper diet. The most important thesis of epigenetics is that the first strand of our DNA code doesn't have to determine a person's life, as there is another biological information system that provides each cell with knowledge of where it comes from, what it has experienced and where it is going. It turns out that stimuli such as upbringing, love, food, hunger, stress, poisoning, nicotine, hormones, experiences in the womb, psychological therapies, trauma, torture, climate or sport can change the cell biochemistry without violating the genetic code. Moreover, cells accumulate a variety of molecular and biological information 
that is not in the genotype, and yet during cell division, they are transferred, along with the genetic material, to daughter cells. Therefore, the question of what features we have inherited from our ancestors, and which we have obtained through upbringing, culture and interactions in our environment, ceases to be relevant in this form. The theory of evolution must be rewritten in significant fragments. Contemporary scientific findings prove that epigenetically accumulated environmental influences are, however, hereditary [46].

If the environment plays a role in changing epigenomes, then a bridge can be created between biological and social processes, which absolutely changes the perception of life [47]. As it turns out, our personal lifestyle influences epigenetic regulation mechanisms in our bodies. To put it simply, epigenetics is a process that allows you to turn individual pieces of the genetic code on and off, changing their impact on a person's life.

For example, regular exercise affects DNA. Based on recent scientific reports, it can be stated with full conviction that physical effort is "deeply rooted" in genes, influencing a number of epigenetic changes in gene expression, and positively affecting health [48] (pp. 1557-1569), [49].

For some time now, there has been a growing number of scientific publications on the influence of negative emotional experiences on genetic material, which is especially important in the context of marginalized groups. Information from genes in a DNA strand may or may not show up, and it is possible that the gene's presence may be influenced by-among other things-stress [50]. This is confirmed by research on people who survived the Holocaust during WW II [51], people who had a difficult childhood [52] and people who grew up in poverty and experienced hunger [53].

Table 1 presents an overview of selected works (publications) that illustrate the relationship between traumatic experiences and the state of social behavior of subsequent generations. The proposed review of research proves that negative attitudes and behaviors may be reversible, but it requires appropriate actions and decisions. It is justified in the context of the purpose of this article.

Table 1. Overview of selected works (publications) that illustrate the relationship between traumatic experiences.

\begin{tabular}{|c|c|c|}
\hline Name and Surname of Researcher & Source Material & Conclusions \\
\hline Mark Wolynn & $\begin{array}{l}\text { IT DIDN'T START WITH YOU. } \\
\text { How Inherited Family Trauma Shapes } \\
\text { Who We Are and How to End the Cycle. } \\
\text { Publication by: Wydawnictwo Czarna } \\
\text { Owca, (Poland) } 2021\end{array}$ & $\begin{array}{l}\text { Depression, anxiety disorders, chronic } \\
\text { pain, or obsessions may not always be the } \\
\text { result of events we have experienced } \\
\text { personally. Their roots sometimes go } \\
\text { back to the time of our parents, } \\
\text { grandparents and even } \\
\text { great-grandparents. Research shows that } \\
\text { traumatic experiences can be passed } \\
\text { down from generation to generation. } \\
\text { Even if the person who experienced the } \\
\text { trauma has long been dead, or the history } \\
\text { of the experience has been forgotten or } \\
\text { passed over in silence, the emotional } \\
\text { traces of the event may still be alive. They } \\
\text { are often deeply hidden, encoded in } \\
\text { genes and language, and can play a much } \\
\text { greater role than previously thought. }\end{array}$ \\
\hline $\begin{array}{c}\text { Arieh Y. Shalev (Editor), } \\
\text { Rachel Yehuda (Editor), } \\
\text { Alexander C. McFarlane (Editor) }\end{array}$ & $\begin{array}{l}\text { International Handbook of Human } \\
\text { Response to Trauma, Springer, } 2000 .\end{array}$ & $\begin{array}{l}\text { Genes can be turned on and off and } \\
\text { expressed in a variety of ways through } \\
\text { changes in environment and behavior; } \\
\text { the conducted research helps to } \\
\text { understand how the effects of stress and } \\
\text { trauma can be passed on biologically, } \\
\text { apart from through single tragic } \\
\text { experiences, to future generations. }\end{array}$ \\
\hline
\end{tabular}


Table 1. Cont.

\begin{tabular}{|c|c|}
\hline Name and Surname of Researcher & Source Material \\
\hline Martha Henriques & $\begin{array}{l}\text { Can the legacy of trauma be passed down } \\
\text { the generations? } \\
\text { https: / / www.bbc.com/future/article/ } \\
\text { 20190326-what-is-epigenetics (accessed } \\
\text { on } 11 \text { August 2021) }\end{array}$ \\
\hline Ewan Birney & $\begin{array}{l}\text { Study of Holocaust survivors finds } \\
\text { trauma passed on to children's genes, } \\
\text { https:/ / www.theguardian.com/science/ } \\
\text { 2015/aug/21/study-of-holocaust- } \\
\text { survivors-finds-trauma-passed-on-to- } \\
\text { childrens-genes } \\
\text { (accessed on 11 August 2021) }\end{array}$ \\
\hline
\end{tabular}

Gita Arian Baack

The Inheritors: Moving Forward from Generational Trauma, Published 13 June 2017 by She Writes Press.
New findings are a clear example in humans of the theory of epigenetic inheritance: the idea that environmental factors can affect the genes of our children.

Family inheritance, both positive and negative, is passed down from generation to generation in ways that are not fully understood yet. Gita Baack calls this secondary form of trauma "inherited trauma" which perpetuates cycles of pain, hatred and violence.

The brain develops best thanks to creativity and enthusiasm. The individual assimilates knowledge better thanks to these two factors, and also,

Who we are-and whom we could be, Gerald Hüther Dobra Literatura (Publication), Słupsk, Poland, 2015. thanks to them, we are able to use more of our potential. The author shows from a neurobiological perspective how anyone can become who they really could be if they used the predispositions they actually possess.

Wolfgang J. Luhan, Martin G. Kocher, Matthias Sutter

Group polarization in the team dictator game reconsidered; Experimental conomics volume 12, pages 26-41 (2009).
There was a correlation between the number of intentional killings (murders) and the level of prosperity in a given country.

Income inequality affects the willingness to use violence. This is due to two factors: mental health and education. People with mental illnesses and without education are particularly affected by such an exclusion. The bigger the differences in living conditions, then the greater the number of such excluded individuals in the entire population of a given country.

Health and education deficits resulting from inequality of opportunity correlate

directly with the percentage of child

Testosterone and Dominance in Men.

Mazur, A. Booth, "Behavioral and Brain Sciences" 21: pp. 353-397 (1998).

births by very young mothers, which in turn correlates directly with the homicide rate.

\section{Source: own study.}

Therefore, it can be assumed that the systemic transformation, which generated enormous social costs, could also be a factor influencing the attitudes and behaviors of those people who were the most affected by the ongoing changes. Here, we have cited only some of the epigenetic studies which more and more often confirm that a change in a 
person's lifestyle affects the health and psyche of their children and grandchildren. The memory of the environment encoded by the cells is passed down to the next generations.

According to J. Bauer, everything we experience between people is perceived by the brain and transformed into biology. This includes, for example, the activation and deactivation of genes. If a child receives many suggestions in the first five years of its life and is given tasks to do, in which he can prove himself, then many genes are created in the child's brain. Nerve growth factors activate and allow this baby's brain to grow.

However, if a child is neglected and does not receive emotional boosts, care and stimulation, then stress genes will be activated. The child feels that it is not good enough and is not liked. According to the latest state of knowledge in modern neuroscience, the brain is largely socially built and socially oriented.

Prof. J. Bauer draws attention to the dangers that may arise from the marginalization of social groups. According to "the law of pain reduction" that he defined, poverty, unemployment, lack of education, and the inability to participate in social life can and does cause social unrest. Social exclusion and humiliation irritate the pain systems of the brain as much as physical pain [54].

People who have experienced exclusion and rejection many times in their lives, and sometimes feel seriously hurt, develop an increased awareness of this painful experience, which triggers fear and aggression in them. Being subjected to day-to-day violence obviously involves a denial of self-respect and honor, and a denial of a place in the human community, which is a fundamental human right. Fear, coupled with aggression, potentially sets in motion a spiral of violence.

Poverty and lack of access to education correlate significantly with aggression and acts of violence. Bauer impressively describes the social outbursts that result in systematic exclusion from the community and humiliation of entire social groups, and the political and pedagogical measures that should be taken, that are both therapeutic and, above all, prophylactic. Not only does the individual obey "the law of the pain limit", but this also relates to entire social groups.

The results of the available studies confirm the problem-genetic typology of areas at risk of permanent marginalization. Although the field teams worked separately and did not communicate with each other when identifying development barriers, the nature of these barriers turned out to be very similar within the category of "problematic areas". This leads to a reflection that when developing new support programs for problem areas, it is also worth referring to their specificity resulting from the genesis of developmental delay-the consequences of systemic transformation.

The methods of neuroscience, when used correctly, help to understand more deeply and broadly the mechanisms of many types of behavior. In the light of neuroscience, the key concept is neuroplasticity of the brain and the inheritance of the so-called "second code" that epigenetics deals with. Starting with neuroplasticity, it was Marian Diamond who explored the issues of neuroplasticity and brain enrichment, which challenged previous knowledge about the brain and genetics, and the invariability of the brain's potential. The most important conclusion from these studies is that the brain is not determined by genetics, but it is influenced by the environment. The most important factors from the environment that positively influence the development of the brain are: proper diet, exercise, overcoming difficulties, novelty, education, hunger, psychotherapy, as well as care and love [55]. It is especially important in critical periods of human development, when beliefs about ourselves and the world, as well as our own potential are being formed: what can we do, what can't we do, how should we live?

\subsection{Creation and Strengthening of Development Factors in Problem Areas-Revitalization Education}

In dysfunctional environments, the child receives a package of negative experiences (which will be discussed later), but also that child receives changes in the brain as a result of traumatic experiences. These changes are caused by overactivity of the hormones adrenaline (epinephrine) and noradrenaline (norepinephrine). Constant stress causes 
these hormones to become overactive, which causes structural changes to neurons, and changes to the genes themselves. One of the most important neurotransmitters-serotoninmodulates all human emotions. When levels of serotonin are too low and there are high levels of noradrenaline (norepinephrine) it induces aggressive and violent behavior. Also, levels of noradrenaline (norepinephrine) that are too low are the cause of risky, impulsive and affect-filled behavior, alcoholism and depression. The level of serotonin and noradrenaline (norepinephrine) is influenced, by parental alcoholism or drug addiction, and steroid use, amongst other things. Aggressive behavior is also caused by lead poisoning, which upsets the body's chemical balance. In families with higher levels of domestic violence, the monoamine oxidase A enzyme-the aggression gene-was detected. This enzyme is only disclosed in the male population. Nowadays, science can partially balance the chemistry of the brain and especially increase the level of serotonin. In addition to medication, the brain can also be balanced with healthy habits.

Thus, the traumatic experiences of a child in early development can affect serotonin and noradrenaline (norepinephrine) levels. Physical and mental development are also disrupted by parental drug and alcohol consumption, which shapes the individual's early behavioral matrix.

Other factors influencing the mental and physical development of a person are: malnutrition and improper diet as well as poisoning (e.g., with lead and mercury). Unfortunately, most modern children are overfed and malnourished at the same time. The brain is particularly malnourished. Modern food, especially the cheapest foods (most often consumed by marginalized groups) have very low nutritional value. In experiments conducted by $\mathrm{M}$. Taraszkiewicz with school-age children who were characterized by hyperactivity, violent behavior and learning difficulties, a monthly "life diet" plan was used in cooperation with their parents, which consisted of:

- not consuming "junk food" (e.g., sweets, crisps, Coca-Cola/Pepsi drinks and other highly processed foods with low nutritional value);

- $\quad$ parents were, in addition, asked to give their children drinking water;

- 15 min reading together. (Parents were instructed accordingly).

The school-aged children, took part in 30-h workshops, the aim of which was to reconstruct their unfavorable experiences. The effects were amazing. The group of students labeled "the worst class in the school", after a month of interaction, were considered active, calm and competent and changed for the better.

Similar effects were observed in a large group of students (approx. 20,000 children) who took part in the projects "I can learn" and "I can. I know. I recognize. I'll do it myself" (in 2007-2013) [56]. Students with great learning and behavioral difficulties participated in these projects. After $40 \mathrm{~h}$ of specially designed experiments, the expected transformation had taken place with almost $100 \%$ rate of success. These changes have also happened to students, teachers and parents who were taking part in the experiment.

In this case, the method of transformation of beliefs and the method of reconstruction/supplementation of missing competences were used, not only in relation to learning skills, but also directed towards self-reliance, self-confidence, self-efficacy and self-esteem.

Research shows that breakthrough life experiences have the strongest impact on the change of an individual person. Experiences changing the established image of oneself and the world, e.g., a change from "I'm weak, I can't do anything", to "I know and I can, I'm good, I'm OK." Or: "life is a jungle where you have to fight to survive", to "the world is generally friendly, and I know how to deal with problems". Or: "school and teachers ... it's not for me, I'm good for nothing", to "I am important and competent".

Experiencing a "better self" is a turning point. Such negative experiences were felt, for example, by women serving prison sentences. With the help of art therapy and repressed emotions therapy, a change of attitude was observed in them and new perspectives were built. One of the ways to participate in this program was to take part in a make-up workshop. Beauticians, hairdressers and stylists worked with the women who were then 
shown their new images. For many of them it was a breakthrough that changed their life decisions towards better prospects.

A very interesting experiment was carried out by M. Lippman [57] in schools in a New York district. Life in that part of the city is characterized by poverty, violence, gangs and hopelessness. Lipman taught students to think in terms of cause and effect, logic, researching their own beliefs, etc., using philosophizing. The changes were spectacular.

As we can see, helping marginalized and disadvantaged groups learn the methodology of interaction resulting from neurosciences and epigenetics results in a significant reconstruction of acquired experiences, changing one's beliefs and equipping them with new competences that are inclusive of the positive current of events. It also influences a change to one's lifestyle.

Only such deep interactions make it possible, strictly speaking, to break out of the loop of negative experiences acquired in childhood and in the environment in which people grew up or lived in. Only such interactions affect permanent changes in the brain, and thus the emergence of new functional formats of behavior. Nobody wants to be excluded from the world in which they live.

The current social support system, instead of preventing helplessness, perpetuates it, often forever. For most disadvantaged people, social assistance is a method of life, it shapes passive attitudes instead of teaching them action in their lives. Social welfare in the form of vouchers for free food, clothes or monthly workouts in the gym only perpetuates helplessness, creating additional addiction-dependence on social welfare.

J. Bauer in the book entitled "The Limit of Pain" wrote that a state that does not give parents sufficient opportunities for intensive care of their children early in life, later pays a high price in the form of an increase in the number of mental disorders, in particular depression and other stress-induced illnesses [45].

"There are many indications that children born in families with low socio-economic status drew a shorter match" [58]. Unfortunately, this generally strongly influences their future fate.

Prof. Heckman, a Nobel laureate at the University of Chicago, school of economics states:

Firstly: investing in children from disadvantaged families is a rare, outstanding public initiative, promoting equal treatment and social justice while supporting the productivity of the economy and society as a whole [59]. Moreover, it is best taken in early childhood. The interplay of genotype and environment influences brain architecture and skill development. Which means that the interplay of genes and experiences is important for the developing brain, which is extremely plastic and particularly sensitive to environmental influences in early childhood.

Secondly, the acquisition of skills is subject to hierarchical rules. You must first master the basic skills before moving on to the next level.

Thirdly, skills are interdependent and influenced by experience.

Fourthly, there are periods of increased sensitivity when the brain is at its most pliable.

Heckman's four assumptions fit perfectly with the results of behavioral genetics research showing that the influences of the common environment are most important in the preschool period.

On average, genes explain about half of the individual differences in cognitive abilities. The environment and upbringing are responsible for the other half.

While socio-economic status is a predictor of school achievement and is influenced by genes, the best path to take is to develop social interventions that take into account environmental influences to reduce the effects of poverty, limited stimulation, overpopulation and chaos if the goal is indeed to equalize opportunities. Any problems will not be solved by acting on the level at which they manifest themselves.

In this section, the author tried to show that the biological approach has a lot to offer to economists and decision makers. Well-interpreted research using the methods of neuroscience may not only contribute to a deeper, multidisciplinary understanding 
of the social phenomena, but also positively influence the development of theories in this discipline.

The presented issues confirm the author's belief that making decisions in the area of human resource management can be considered in terms of economic conditions (labor demand/supply), but also in neural conditions, examining human internal mechanisms and drawing conclusions about individual "differences" between people. Knowledge about the neuronal aspects of trust, empathy, and the role of the brain seems to be important in a world where the concept of managing people is accused of being manipulative.

According to the latest research in the field of epigenetics (extra-gene inheritance) there is a second code of inheritance of behavior. The image of the world, and thus also mentality and life attitudes, allow us to explain the multigenerational inheritance of social inertia, helplessness, anti-social attitudes, and negative and nondevelopmental life patterns. Traditional education at school is not able to eliminate these negative patterns; on the contrary, it consolidates social stratification and does not give future generations any chance for a better change in this domain. Effective programs are needed to change mentality and build resourcefulness in life for the youngest children, as well as programs for young parents (shaping the mentality) of the young generation and programs for intergenerational integration.

The idea of revitalization education assumes the integration and inclusion of students from neglected environments. The basis for reaching these students should be competence in building relationships. This requires specialists (psychologists, therapists, neurobiologists) to develop programs that will be dedicated to teachers so they can help children to develop the desired competences, and their additional effect will be health prophylaxis for teachers (preventing professional burnout).

The vast majority of graduates who leave educational institutions do not acquire any of the features that prepare them for life: self-confidence, internal motivation, solid knowledge, and social and emotional competences. Thanks to revitalization education, the school can become a friendly place for all participants of the educational process.

Additionally, it is required to train moderators who, based on the prepared programs, will then conduct training with teachers, children, the youth and their parents.

\section{Conclusions and Recommendations}

The development of brain imaging techniques is a huge step forward in the field of medicine. However, the technologies that allow diagnosis of patients' brains are also applicable in nonmedical areas. Correctly used methods of neurosciences help to understand more deeply and broadly the mechanisms of many behaviors, including the behavior of people from problem areas. Therefore, it is necessary to refer to the available results from research by neurobiologists and the conclusions drawn from them in order to more effectively program activities that are addressed to marginalized and socially excluded people.

Revitalization education should be directed at people who are caught up in a negative loop of social patterns. Since the children's fate is shaped by the influence of their parents and teachers, the actions of reconstructing positive life patterns, prodevelopment skills and competences should also be directed at parents. In this way, the challenges and social problems of problem areas will be solved in a comprehensive and systemic way, with a focus on long-term effects that will translate into mental, existential and educational changes and, in the longer term, will contribute to the socio-economic development of problem areas.

Based on the above, the author of this text believes that:

- co-financing poverty only perpetuates incorrect patterns of behavior and beliefs, thereby perpetuating the phenomenon that is to be worked through and solved;

- the instrument of change is a system of properly profiled education and properly designed educational programs-revitalization education; 
- to this end, educational genetics should form a fundamental part of all educational programs for educators and people dealing with social assistance and social policy, as well as doctors and people dealing with perinatal care;

- solving social problems through financial and material help is "magical thinking", consolidating characteristic negative and nonproductive attitudes, beliefs and values that are antidevelopmental for the concerned individual as well as for the society as a whole;

- there is a need to educate specialists in the field of revitalization activities in education and the development of social intervention programs (using the conclusions from research in the field of neurosciences and epigenetics), the aim of which is to cause a permanent change for disadvantaged and socially excluded people/groups.

In the long run, this will prove beneficial both socially and economically for individuals and society as a whole.

Regarding decision making, epigenetics teaches us that:

- whoever invests in education also supports the health and learning capacity of future generations;

- whoever in a targeted way improves the situation of future parents, newborns and young children, does something for the later education of children and adolescents.

- investment in education starts with fighting poverty and inequality.

The findings presented in this study are in line with the commonly emphasized need to evaluate the current practices of the European cohesion policy and to identify more effective actions shaping and strengthening the development factors, taking into account contemporary challenges of regional policy $[60,61]$. The proposed new approach to educational policy in problem areas aims to ensure an increase in the effectiveness of public policy interventions by providing beneficiaries with an integrated and coherent package of positively strong experiences (existential, educational) thus reconstructing negative life experiences and changing their mentality. This should result in a change in such parameters as: cognitive and life optimism, sense of internal control, life and educational aspirations, sense of educational and life competences. These are the desired changes in attitudes and different types of behavior typical of the population living in problem areas.

Inhabitants of problem areas should be equipped with new skills and competences as well as courage in life (in the formula of psychotherapy and revitalization education), in order to make conscious choices in life and in professional scenarios, which will significantly improve their quality of life and increase their well-being (i.e., according to the official WHO definition: human subjective satisfaction with physical, mental and social life). A package of revitalization measures should be designed that go on to be used as a strong phase of flooding beneficiaries with positive and tested models of functioning that build socially desirable life patterns in a permanent manner. First of all, activities should be directed towards children who are caught up in the negative loop of social patterns. Since their fate is shaped by the influence of their parents and teachers, they should also be involved in the parallel activities of reconstructing life patterns for prodevelopment skills and competences. In this way, social challenges and problems will be solved in a holistic and systemic way, with a focus on long-term effects that will translate into mental, existential, educational and, in the longer term, socio-economic changes.

Funding: This research received no external funding.

Institutional Review Board Statement: Not applicable.

Informed Consent Statement: Not applicable.

Data Availability Statement: The study did not report any data.

Conflicts of Interest: The author declares no conflict of interest. 


\section{References}

1. European Commission. My Region, My Europe, Our Future: Seventh Report on Economic, Social and Territorial Cohesion; European Commission: Luxembourg, 2017.

2. Chojnicki, Z. Geography and the problems of the contemporary world. In Geography and Changes in the Contemporary World. Basic Ideas and Concepts in Geography, 3rd ed.; Maik, W., Rembowska, K., Suliborski, A., Eds.; University of Economy in Bydgoszcz: Bydgoszcz, Poland, 2007; Volume 3, pp. 15-24.

3. Stavridou, A.; Stergiopoulou, A.A.; Panagouli, E.; Mesiris, G.; Thirios, A.; Mougiakos, T.; Troupis, T.; Psaltopoulou, T.; Tsolia, M.; Sergentanis, T.N.; et al. Psychosocial consequences of COVID-19 in children, adolescents and young adults: A systematic review. Psychiatry Clin. Neurosci. 2020, 74, 615-616. [CrossRef] [PubMed]

4. Singh, S.; Roy, D.; Sinha, K.; Parveen, S.; Sharma, G.; Joshi, G. Impact of COVID-19 and lockdown on mental health of children and adolescents: A narrative review with recommendations. Psychiatry Res. 2020, 293, 113429. [CrossRef]

5. Liu, J.J.; Bao, Y.; Huang, X.; Shi, J.; Lu, L. Mental health considerations for children quarantined because of COVID-19. Lancet Child Adolesc. Health 2020, 4, 347-349. [CrossRef]

6. Shanahan, L.; Steinhoff, A.; Bechtiger, L.; Murray, A.L.; Nivette, A.; Hepp, U.; Eisner, M. Emotional Distress in Young Adults during the COVID-19 Pandemic: Evidence of Risk and Resilience from a Longitudinal Cohort Study. Psychol. Med. 2020, 23, 1-10. [CrossRef]

7. Glowacz, F.; Schmits, E. Psychological distress during the COVID-19 lockdown: The young adults most at risk. Psychiatry Res. 2020, 293, 113486. [CrossRef] [PubMed]

8. Lee, C.; Cadigan, J.; Rhew, I. Increases in Loneliness Among Young Adults During the COVID-19 Pandemic and Association with Increases in Mental Health Problems. J. Adolesc. Health 2020, 67, 714-717. [CrossRef]

9. $\quad$ Liang, L.; Ren, H.; Cao, R.; Hu, Y.; Qin, Z.; Li, C.; Mei, S. The effect of COVID-19 on youth mental health. Psychiatry Q. 2020, 91, 841-852. [CrossRef]

10. Dalton, L.; Rapa, E.; Stein, A. Protecting the psychological health of children through effective communication about COVID-19. Lancet 2020, 4, 346-347. [CrossRef]

11. Maldonado, J.; de Witte, K. The Effect of School Closures on Standardized Student Test; KU Leuven Discussion Paper Series; KU Leuven-Faculty of Economics and Business: Leuven, Belgium, 2020.

12. Hanushek, E.A.; Woessmann, L. The Economic Impacts of Learning Losses; No. 225; OECD Education Working Papers; OECD Publishing: Paris, France, 2020.

13. Wee, S.L. Born under a Bad Sign: The Cost of Entering the Job Market during a Recession; Working Paper; University of Maryland: College Park, MD, USA, 2013.

14. Andrews, D.; Deutscher, N.; Hambur, J.; Hansell, D. The Career Effects of Labor Market Conditions at Entry; OECD Productivity Working Papers; OECD Publishing: Paris, France, 2020.

15. Oreopoulos, P.; von Wachter, T.M.; Heisz, A. The Short- and Long-Term Career Effects of Graduating in a Recession. Am. Econ. J. Appl. Econ. 2012, 4, 1-29. [CrossRef]

16. Schwandt, H.; Till, M.; von Wachter, T.M. Socioeconomic Decline and Death: Midlife Impacts of Graduating in a Recession; NBER Working Paper No. 26638; National Bureau of Economic Research: Cambridge, UK, 2020.

17. Kahneman, D. Maps of bounded rationality: A perspective on intuitive judgment and choice. In Nobel Prizes 2002; Frangsmyr, T., Ed.; Almquist \& Wiksell International: Stockholm, Sweden, 2003.

18. Thaler, R.H. Misbehaving: The Making of Behavioral Economics; W.W. Norton \& Company: New York, NY, USA, 2015.

19. Tykkylainen, M. From Territorial Marginality to Marginality in Cybersociety. In Perceptions of Marginality: Theoretical Issues and Regional Perceptions of Marginality in Geographical Space; Jussila, H., Leimgruber, W., Majoral, R., Eds.; Ashgate: Aldershot, UK, 1998 ; p. 123.

20. Eskelinen, H.; Snickars, F. Competitive European Peripheries; Springer: Berlin/Heidelberg, Germany, 1995.

21. Garro, D.B.; Wilson, J.C. Nature on the Edge? Marine Ecotourism in Peripheral Coastal Areas. J. Sustain. Tour. 2004, 12, 95-120.

22. Marada, M.; Chromy, P. Contribution to Studies on Peripheral Regions of Czechia; Acta Facultatis Rerum Naturalium Universitatis Comenianae, Geographica Supplementum, No. 2/1; Univerzita Komenského: Bratislava, Slovakia, $1999 ;$ p. 244.

23. Sommers, L.M.; Mehretu, A.; Piggozi, B.W. Globalization and Economic Marginalization: North-South differences. In Globalization and Marginality in Geographical Space: Political, Economic and Social Issues of Development in the New Millennium; Jussila, H., Majoral, R., Delgado-Cravidao, F., Eds.; Ashgate: Aldershot, UK, 2001; p. 27.

24. Andreoli, M.; Tellarini, V. Marginality and Development in Italy: A study review. In Perceptions of Marginality: Theoretical Issues and Regional Perceptions of Marginality in Geographical Space; Jussila, H., Leimgruber, W., Majoral, R., Eds.; Ashgate: Aldershot, UK, 1998; pp. 101-121.

25. Enyedi, G. Development Issues of Marginal Regions in Hungary. In Marginality and Development Issues in Marginal Regions; Chang, Y., Ed.; Proceedings of Study Group on Development Issues in Marginal Regions; IGU: Taipei, Taiwan, 1994; pp. 63-72.

26. Domański, R. The Rules of Socio-Economic Geography; PWN: Warsaw, Poland; Poznań, Poland, 1995; pp. 173-174.

27. Hoover, E.M. An Introducion to Regional Economic; Alfred Knopf Inc.: New York, NY, USA, 1971; 262p.

28. Chinitz, B. The regional Problem in the USA. In Backward Areas in Adranced Conntries; Robinson, E.A.G., Ed.; Macmillan: London, UK; St. Martins Press: New York, NY, USA, 1969; p. 53. 
29. Mync, A. Miejsce Austrii w Europie. Aspekty regionalne. In Wspótczesne Aspekty Gospodarki Przestrzennej Polski, Rozwój Regionalny, Rozwój Lokalny, Samorzą Terytorialny; Kukliński, A., Ed.; Wolters Kluwer: Warszawa, Poland, 1989; p. 367.

30. Klekner, P. The Role of Agriculture in the Development of Fringe Areas. In Development Issues and Strategies in the Neww Europe; Tykkylainen, M., Ed.; Avebury: Aldershot, UK, 1992; p. 125.

31. Bański, J. Problem Areas in Polish Agriculture; Geographical Works No. 172; PAN Institute of Geography and Spatial Organization: Warsaw, Poland, 1999; p. 13.

32. Kleer, J. Transformations and related problems. In Economics for Lawyers and More; Bednarski, M., Wilkin, J., Eds.; Wydawnictwo Prawnicze Lexis Nexis: Warsaw, Poland, 2008; pp. 438-460.

33. Gill, I.; Sugawara, N. What Can Countries in Central Europe Do for the European Project? Complete the Convergence, CEPR's Policy Portal. 2013. Available online: http:/ / voxeu.org/article/central-european-reforms-beacon (accessed on 26 October 2017).

34. Dicken, P. Global Shift. Mapping the Changing Contours of the World Economy; The Guilford Press: New York, NY, USA; London, UK, 2015.

35. Wallerstein, I. World-Systems Analysis. An Introduction; Duke University Press: London, UK, 2004.

36. Westernhagen, N. Systemic Transformation, Trade and Economic Growth: Developments, Theoretical Analysis and Empirical Results; Springer: Berlin/Heidelberg, Germany, 2002.

37. Konecka-Szydłowska, B.; Churski, P.; Herodowicz, T.; Perdał, R. The European context of the influence of contemporary mega trends on socio-economic development. A synthetic view. Przeglad Geogr. 2019, 91, 39-59. [CrossRef]

38. Churski, P.; Herodowicz, T.; Konecka-Szydłowska, B.; Perdał, R. Factors of Regional Development in the Light of Contemporary Socio-Economic Changes-Theoretical Discourse; Working Paper of FORSED Project, 1; Institute of Social and Social Geography Economics and Spatial Management of Adam Mickiewicz University: Poznań, Poland, 2017.

39. Churski, P. Place-Based Policy - Theory and Practice of Regional Policy; Regional Development and Regional Policy; Institute of Socio-Economic Geography and Spatial Management AMU: Poznań, Poland; Bogucki Wydawnictwo Naukowe: Poznań, Poland, 2018; Volume 41, pp. 31-50.

40. United Nations. Report of the Secretary-General-Promoting Empowerment of People in Achieving Poverty Eradication, Social Integration and Full Employment and Decent Work for All; E/CN.5/2013/3; United Nations: New York, NY, USA, 2012.

41. Dwivedi, O.P.; Khator, R.; Nef, J. Marginalization and Exclusion. In Managing Development in a Global Context; Palgrave Macmillan: London, UK, 2007; pp. 62-69.

42. Kipling, D.; Williams, A.; Carter-Sowell, R. Marginalization through social ostracism: Effects of being ignored and excluded. In Coping with Minority Status; Butera, F., Levine, J.M., Eds.; Cambridge University Press: Cambridge, UK, 2009 ; pp. 104-122.

43. Simmons, R.; Thompson, R.; Russell, L. Poverty, Social Exclusion and Marginalization, Education, Work and Social Change; University of Huddersfield: Huddersfield, UK; pp. 18-38.

44. Active Social Inclusion, Sub-Measure 9.2.1; No. RPKP.09.02.01-IZ.00-04-051/16; Annex No. 2 to Resolution No. 32/1282/16 of the Kujawsko-Pomorskie Voivodeship Board of 23 August 2016; Marshal's Office of the Kujawsko-Pomorskie Voivodeship: Toruń, Poland, 2016.

45. Bauer, J. The Limit of Pain. About the Sources of Aggression and Violence; Dobra Literatura: Słupsk, Poland, 2015.

46. Spork, P. The Second Code. Epigenetics, or How We Can Control Our Own Genotypes; W.A.B.: Warsaw, Poland, 2011.

47. Szyf, M.; McGowan, P.; Meaney, M.J. The social environment and the epigenome. Environ. Mol. Mutagen. 2008, 49, 46-60. [CrossRef] [PubMed]

48. Lindholm, M.E.; Marabita, F.; Gomez-Cabrero, D.; Rundqvist, H.; Ekstrom, T.J.; Tegner, J.; Sundberg, J. An integrative analysis reveals coordinated reprogramming of the epigenome and the transcriptome in human skeletal muscle after training. Epigenetics 2014, 9, 1557-1569. [CrossRef] [PubMed]

49. Głowacki, Ł. Physical Activity and Genes Part I-Muscles. Available online: https://biotechnologia.pl/biotechnologia/ aktywnosc-fizyczna-a-geny-czesc-i-miesnie,16456 (accessed on 21 July 2020).

50. Unternaehrer, E.; Luers, P.; Mill, J.; Dempster, E.; Meyer, A.H.; Staehli, S.; Lieb, R.; Hellhammer, D.H.; Meinlschmidt, G. Dynamic changes in DNA methylation of stress-associated genes (OXTR, BDNF) after acute psychosocial stress. Transl Psychiatry 2012, 2, 1-7. [CrossRef] [PubMed]

51. Yehuda, R.; Daskalakis, N.P.; Bierer, L.M.; Klengel, T.; Holsboer, F.; Binder, E.B. Holocaust Exposure Induced Intergenerational Effects on FKBP5 Methylation. Biol. Psychiatry 2016, 80, 372-380. [CrossRef] [PubMed]

52. Kumsta, R.; Marzi, S.J.; Viana, J.; Dempster, E.L.; Crawford, B.; Rutter, M.; Mill, J.; Sonuga-Barke, E.J. Severe psychosocial deprivation in early childhood is associated with increased DNA methylation across a region spanning the transcription start site of CYP2E1. Transl. Psychiatry 2016, 6, 1-7. [CrossRef] [PubMed]

53. Swartz, J.R.; Hariri, A.R.; Williamson, D.E. An epigenetic mechanism links socioeconomic status to changes in depression-related brain function in high-risk adolescents. Mol. Psychiatry 2016, 22, 209-214. [CrossRef] [PubMed]

54. Bauer, J. Wo gehts hier zur dunklen Seite? Wien. Ztg. 2011, 5, 1-2.

55. Dr. Diamond-My Love Brain. Available online: https:/ /www.youtube.com/watch?v=WR_cEutJNPo (accessed on 20 July 2019).

56. Taraszkiewicz, M. POKL project "I Can Learn" and "I Can. I Know. I Recognize. I'll Do It Myself". Available online: http:/ / kiw-pokl.org.pl/media/upload/951/Raport\%20z\%20ewaluacji\%20zewn\%C4\%99trznej.pdf (accessed on 20 May 2019).

57. Lipman, M. Philosophy in School; CODN: Warsaw, Poland, 2008.

58. Asbury, K.; Plomin, P. Genes and Education; PWN Publication: Warsaw, Poland, 2017. 
59. Heckman, J.J. Investing in Disadvantaged Young Children Is an Economically Efficient Policy. In Proceedings of the Committee for Economic Development/The Pew Charitable Trusts/PNC Financial Services Group Forum on "Building the Economic Case for Investments in Preschool", New York, NY, USA, 10 January 2006.

60. Bachtler, J.; Ferry, M. Conditionalities and the Performance of European Structural Funds: A Principal—Agent Analysis of Control Mechanisms in European Union Cohesion Policy. Reg. Stud. 2015, 49, 1258-1273. [CrossRef]

61. Brandsma, A.; Kancs, D. RHOMOLO: A Dynamic General Equilibrium Modeling Approach to the Evaluation of the European Union's R\&D Policies. Reg. Stud. 2015, 49, 1340-1359. 